\title{
ENTOMOLOGICAL PARAMETERS AND CHARACTERIZATION OF INSECTICIDE RESISTANCE IN DENGUE VECTOR AEDES AEGYPTI LARVAE FROM BENGKULU CITY, INDONESIA
}

\author{
Dessy Triana ${ }^{1 *}$, Fitaloca N Siregar ${ }^{2}$, Eka Purnama Wulan Tri Utami ${ }^{2}$, Tatik Suteky ${ }^{3}$ and Swandito \\ Wicaksono ${ }^{4}$ \\ ${ }^{1}$ Department of Parasitology, Faculty of Medicine and Health Sciences Universitas Bengkulu, Indonesia \\ ${ }^{2}$ Undergraduate Program of Medicine, Faculty of Medicine and Health Sciences Universitas Bengkulu, Indonesia \\ ${ }^{3}$ Department of Farming, Faculty of Agriculture Universitas Bengkulu, Indonesia \\ ${ }^{4}$ Department of Physiology, Faculty of Medicine and Health Sciences Universitas Bengkulu, Indonesia
}

Corresponding author: Dessy Triana

Email: dessy.triana@unib.ac.id

\begin{abstract}
In Bengkulu, as in other areas of Indonesia, dengue is one of the most important vector-borne diseases. The primary strategy to control dengue is by reducing the vector population using insecticides. However, applications of insecticides becomes a contributing factor in the development of vector resistance. As there is no effective dengue drug or safe vaccine available, vector control remains the most effective intervention to reduce incidence and prevent transmission and outbreak. This study aimed to determine the entomological parameters and resistance status to temephos of Aedes aegypti larvae from Lingkar Barat village and Jalan Gedang village (dengue endemic areas). This study used crosssectional and experimental with post-control only design. The sampling refers to the guidelines for dengue entomology surveys according to WHO 1999 criteria. Aedes aegypti eggs were collected by ovitraps and reared to larvae stage. Susceptibility test of larvae to the temephos was estimated using standard WHO. Mortality of larvae Ae. aegypti after 24 hours with multiple concentration of temephos indicative of highly resistant. Entomological parameters for house index $(\mathrm{HI})$, container index $(\mathrm{Cl})$ and container pupa index $(\mathrm{CPI})$ in Jalan Gedang village and Lingkar Barat village were estimated: $7 \%, 12 \%$ for $\mathrm{HI}$ and $1.97 \%, 3.43 \%$ for $\mathrm{Cl}$, and 5\%, $2 \%$ for CPI, respectively. The proportion of controllable sites is higher than disposable sites, it has a high risk as breeding places for mosquitoes indicates a high potential risk as breeding place and transmission of dengue. Awareness sanitation in the home and surrounding environment must be possessed by each individual community in order to prevent and overcome the incidence of dengue. These data should be of value in formulating dengue control programs.
\end{abstract}

Keywords: Dengue, Aedes aegypti, Aedes albopictus, Entomological Parameter, Insecticide Resistance

\section{INTRODUCTION}

Dengue is an emerging public health problem globally, estimated to occur annually in over 100 endemic countries, putting almost half of the world's population at risk. ${ }^{1,2}$ The incidence rate (IR) of dengue by province in 2018 in Indonesia showed the highest incidence rate of DHF were East Kalimantan at 87.81 per 100,000 population, Central Kalimantan at 84.39 per 100,000 population, and Bengkulu at 72.28 per 100,000 population. The incidence rate in the province of Bengkulu increased, twice compared to that in 2017, from 31.95 to 72.28 per 100,000 population. Bengkulu City, with 8.487 dengue patients and a moratlity of 108 , became designated a high risk region for dengue infection. ${ }^{3}$

Dengue hemorrhagic fever (DHF) is an endemic disease that occurs throughout the year, usually in the rainy season because of the Aedes mosquitoes population, which can develop optimally in the community. In the past 50 years, the incidence of dengue has increased 30 -fold, with an increase in geographical expansion to new countries, and expansion from urban to rural areas. $n$ estimated
50 million dengue infections occur every year, and around 2.5 billion people live in the 128 endemic countriess. ${ }^{4}$

Vector control remains the only available intervention to prevent and control the transmission of dengue. ${ }^{4}$ Due to continuous exposure to insecticides, several insect have developed resistance to this chemical. Temephos and malathion, an organophosphate have been the main insecticide for mass larvaciding and fogging in Indonesia, respectively. ${ }^{5}$ However, long-term use of this chemical have contributed to the development of resistance by Ae. aegypti. ${ }^{6,7}$

The key to dengue disease control programs relies on vector control to minimize the transmission of the dengue virus. Some ecological, biological and climatic factors have a close relationship in vector breeding and virus transmission, because the risk of virus development is directly or indirectly related to seasonal changes in climate and the index of mosquito larvae. ${ }^{9}$ Vector surveillance is the most important aspect of vector control programs. The purpose of vector surveillance is to 
obtain information about the presence, frequency, number and distribution based on place and time, changes in density, distribution and other epidemiological parameters related to vectorial capacity. ${ }^{5}$ The larval survey indicators used are the Container Index $(\mathrm{Cl})$ and the House Index (HI). A pupa survey can provide important information to help achieve vector control activity targets. ${ }^{10}$ The total number of pupae Aedes $s p$ is used as the closest indicator to predict the number of adult mosquitoes. ${ }^{11}$

Mosquitoes breed in various habitats such as ponds, marshes, ditches, pools, drains, water containers, tree holes, etc. ${ }^{8,9}$ The cycle of Aedes mosquitoes is strongly influenced by availability of water sources and climate changes. Human ecology is responsible for the creation of mosquitogenic environment; humans directly or indirectly create such a situation. ${ }^{10,11}$

The vector ecology of Aedes sp includes climate (temperature and rainfall), the existence of breeding and resting sites, opportunities to obtain food, and vectorial capacity. The results of research conducted by Arunachalam (2010) in six countries, namely Indonesia, India, Myanmar, the Philippines, Sri Lanka and Thailand, showed that the vector ecological factor that most affected the density of dengue vectors was the availability of breeding sites and mosquito resting places. ${ }^{11}$

In 2017, Bengkulu Province was ranked $10^{\text {th }}$ out of 34 provinces in Indonesia for dengue cases. It has a high dengue incidence rate (IR), at 31.95 per 100,000 population, and a case fatality rate (CFR) of $0.81 \% .{ }^{15}$ Bengkulu City is one of the high dengue-endemic areas in Bengkulu Province, and Gading Cempaka District, Bengkulu City has also been one of the high endemic dengue districts since 2008. In 2016, there were 171 cases, with an IR of 386 per 100,000 population and a CFR of $3.6 \%$. Gading Cempaka District still ranks as highly endemic, so this research was conducted in two villages of Gading Cempaka District, namely Lingkar Barat and Jalan Gedang. Lingkar Barat and Jalan Gedang both have highly endemic dengue, but the characteristics of the area are different, in Lingkar Barat the dominant population is densely populated while in Jalan Gedang the office building is dominant. The study aimed to determine the entomological parameters and characterization of insecticide resistance in dengue vector Ae. aegypti larvae in Gading Cempaka District, Lingkar Barat village and Jalan Gedang village. Susceptibility of larvae to the temephos was estimated using standard of WHO and entomoligcal parameters was estimated using WHO guidelines for three parameters (house index, container index, and container pupa index).

\section{METHODS}

\section{Study Design and Sampling}

This research was conducted in October 2019 and has been approved by Health Research Ethics Commite of the Faculty of Medicine and Health Sciences Universitas Bengkulu, with numbers 305/UN30.14.9/LT/2019. The design of this study was experimental with post-control only.

\section{Data Collection}

Observations and measurements were repeated at the research location so that the data would be more accurate. The research was conducted in Lingkar Barat village and Jalan Gedang village, Gading Cempaka District, Bengkulu City between November and December 2019.

The research sample were houses to be surveyed that had a dengue case, together with the surrounding houses within a radius of 100 meters. The sampling method refers to the guidelines for dengue entomology surveys according to WHO 1999 criteria, using the number of houses and the house index $(\mathrm{HI})$ data in the study location (Table 1). ${ }^{17}$

\section{Entomological Parameters}

All the possible water containers were sampled for mosquito larvae and immature, both indoors and outdoors. Threre were a total of 704 container categories surveyed in this study. Three parameters like House Index (HI), Container Index $(\mathrm{Cl})$ and Container Pupa Index (CPI) were worked out as per WHO guidelines. ${ }^{17,18}$ Shannon-Weiner diversity index ${ }^{19}$ is commonly used to characterize species diversity in a community, according to both abundance and evennes of the species present.

The calculation of larval indices is based on the following mathematical formulae:

House Index $(\mathrm{HI})=\frac{\text { Number of houses infested }}{\text { Total number of houses inspected multiplied by } 100} \times 100$
Container Index $(\mathrm{CI})=\frac{\text { Number of positive containers infested }}{\text { Total number of containers inspected multiplied by } 100} \times 100$
Container Pupa Index (CPI) $=\frac{\text { Number of pupa positive containers }}{\text { Total number of containers inspected multiplied by 100 }} X 100$


Mosquito eggs collection

Mosquito eggs were collected from dengue endemic area (Lingkar Barat Village and Jalan Gedang Village) in Bengkulu City. A total of 110 to 120 ovitraps were distributed for each area in a radius of $100 \mathrm{~m}$ from households of patients suffering from DHF/DSS randomly selected. A total of 230 ovitraps were distributed. Based on table 1 , the research area has the number of buildings from 5000 to 10.000 and house index $>5 \%$.

Table 1. Number of houses inspected by House Index

\begin{tabular}{cccc}
\hline Number of buildings & \multicolumn{2}{c}{ House Index $(\mathrm{HI})$} \\
\hline & $>1 \%$ & $>\mathbf{2} \%$ & $>5 \%$ \\
\cline { 2 - 4 } 200 & 95 & 78 & 45 \\
300 & 155 & 105 & 51 \\
400 & 189 & 117 & 54 \\
500 & 211 & 124 & 55 \\
1000 & 225 & 129 & 56 \\
2000 & 258 & 138 & 57 \\
5000 & 277 & 143 & 58 \\
10.000 & 290 & 147 & 59 \\
unlimited & 294 & 148 & 59 \\
\hline
\end{tabular}

Source: (WHO, 2011)

\section{Colonization}

The collected eggs were colonized in the Laboratory of Parasitology Department of Faculty of Medicine and Health Sciences Universitas Bengkulu, Indonesia. Mosquitoes were reared under insectary conditions of $25 \pm 2^{\circ} \mathrm{C} ; 75 \pm 10 \%$ relative humidity, and a $12 \mathrm{~h}$ light: $12 \mathrm{~h}$ dark photoperiod with a $10 \%$ sucrose solution as mosquito feed. ${ }^{19}$ Adult mosquitoes were identified to determine Ae. aegypti. Colonization of the mosquitoes was continued to the F1 generation of third instar larvae for bioassay. The larvae were placed in dechlorinated water in a pan $30 \mathrm{~cm}$ by $20 \mathrm{~cm}$ kept at a temperature of 25 $\pm 2^{\circ} \mathrm{C} ; 75 \pm 10 \%$ relative humidity with dried beef liver as larval feed.

\section{Larval Bioassay}

Susceptibility of larvae to the temephos was estimated using standard of WHO. ${ }^{(19,20)}$ The stock solution of $1 \mathrm{ppm}$ and dilutions was prepared in $95 \%$ ethanol and stored at $\pm 4^{\circ} \mathrm{C}$ for use in the experiment. Bioassay were conducted using 20-25 third instar larvae in plastic cup at room temperature $\left(25 \pm 2^{\circ} \mathrm{C}\right)$. Five different concentrations $(0.003,0.006,0.012,0.024$ and $0.048 \mathrm{ppm}$ ) were used and each experiment was replicated at least four times. Each bioassay was accompanied by control test to wich only aquadest was added in equal concentration. Corrected mortality was calculated after 24 hours and the larvae were considered dead if they did not show any movement when induced with a glass rod.

\section{Data Analysis}

Mortality obtained was corrected using Abbott's Formula ${ }^{21}$ and interpreted following WHO recommendation. If the number of control mosquitoes died between $3-10 \%$, the mortality was calculated using Abbott's Formula. If the number of control mosquitoes died was $>10 \%$, the test should be repeated. Abbott's formula is as follows:

$$
=\frac{\begin{array}{c}
\text { Abbott's Formula } \\
\% \text { mortality in test }-\% \text { mortality in control }
\end{array}}{100-5 \text { mortality in control }} \times 100 \%
$$

The percentage of mortality was classified into 3 categories according to WHO, namely: $98 \%-100 \%$ (highly susceptible), $80 \%-97 \%$ (moderately resistant/verification required) and $<80 \%$ (highly resistant). ${ }^{20}$ Data from larval bioassays were analyzed using one way of variance (ANOVA), with significance accepted at $\mathrm{p}<0.05$ and probit analysis from Statistical Program for Social Science (SPSS) Version 24. Lethal concentrations $\left(\mathrm{LC}_{50}\right.$ and $\left.\mathrm{LC}_{90}\right)$ along with the slope were estimated at $95 \%$ confidence intervals.

\section{RESULTS}

\section{Climate and Entomological Parameters}

During the research (November 2019, 20 ${ }^{\text {th }}-30^{\text {th }}$ ) conditions of $26.83^{\circ} \mathrm{C} ; 86.54 \%$ relative humidity, rainfall rate $1.09 \mathrm{~mm} .{ }^{21}$ The entomological survey results obtained from the study are presented in several larval indices, namely the house index $(\mathrm{HI})$, container index $(\mathrm{Cl})$ and Container Pupa index (CPI). The highest $\mathrm{HI}$ parameter is in Lingkar Barat village, at $12 \%$. The larval indicators can be seen in Table 2.

The house index is one indicator used to calculate the risk of disease transmission. This index provides a clue as to the percentage of positive houses where Aedes sp mosquitoes breed, increasing the risk of dengue events. In this study, out of the 100 houses examined in each village, namely Jalan Gedang and Lingkar Barat, this percentage was $7 \%$ and $12 \%$ respectively. $\mathrm{HI}>10 \%$ indicates that the area already has a dengue case. The $\mathrm{HI}$ rate in Jalan Gedang village of $7 \%$ 
illustrates that the area has a high risk of dengue transmission, meaning that more adequate preventive measures are needed. ${ }^{22}$

The entomology survey also looked at container types in the form of controllable sites (CS) and disposable sites (DS). The most container found in Jalan Gedang was tubs (23.16\%), while in Lingkar Barat village it was vase $(23.43 \%)$.
The most positive type of larvae container found in Jalan Gedang was tubs (1.13\%), while in Lingkar Barat village it was vase $(1.42 \%)$ in Table 3.

\section{Larval Bioassay}

Larvae mortality after a 24 hours exposure to temephos at discriminating doses indicated that the Aedes aegypti from Jalan Gedang Village and Lingkar Barat Village in Bengkulu City was classified as highly resistant to temephos (Table 4).

Table 2. Entomological Parameters in Jalan Gedang Village and Lingkar Barat Village, Bengkulu City

\begin{tabular}{lccc}
\hline Location & House Index (\%) & Container Index (\%) & $\begin{array}{c}\text { Container Pupa Index } \\
(\%)\end{array}$ \\
\hline Jalan Gedang & 7 & 1.97 & 5 \\
Lingkar Barat & 12 & 3.43 & 2 \\
\hline
\end{tabular}

Table 3. Number and Type Containers

\begin{tabular}{|c|c|c|c|c|}
\hline \multirow[t]{3}{*}{ Container } & \multicolumn{4}{|c|}{ Village } \\
\hline & \multicolumn{2}{|c|}{ Jalan Gedang } & \multicolumn{2}{|c|}{ Lingkar Barat } \\
\hline & Total & $\begin{array}{c}\text { Positive } \\
\text { Container }\end{array}$ & Total & $\begin{array}{c}\text { Positive } \\
\text { Container }\end{array}$ \\
\hline \multicolumn{5}{|l|}{ Controllable Site } \\
\hline Water reservoir & 24 (6.78\%) & & 58 (16.57\%) & \\
\hline Tubs & 82 (23.16\%) & $4(1.13 \%)$ & $36(10.29 \%)$ & $4(1.14)$ \\
\hline Jugs & 14 (3.96\%) & & $8(2.29 \%)$ & \\
\hline Pails & 76 (21.47\%) & $2(0.56 \%)$ & $46(13.14 \%)$ & $1(0.29 \%)$ \\
\hline Trash bin & $8(2.26 \%)$ & & $4(1.14 \%)$ & \\
\hline Ponds & $10(2.82 \%)$ & & $16(4.57 \%)$ & \\
\hline Vase & 68 (19.21\%) & $1(0.28 \%)$ & $82(23.43 \%)$ & $5(1.42 \%)$ \\
\hline Tree hole & 40 (11.30\%) & & $26(7.43 \%)$ & \\
\hline Pet drinking & $6(1.70 \%)$ & & 48 (13.71\%) & $1(0.29 \%)$ \\
\hline \multicolumn{5}{|l|}{ Disposable Site } \\
\hline Used tire & 10 (2.82\%) & & $0(0 \%)$ & \\
\hline Bucket & $16(4.52 \%)$ & & $26(7.43 \%)$ & $1(0.29 \%)$ \\
\hline Total Containers & 354 & 7 (1.97\%) & 350 & $12(3.43 \%)$ \\
\hline
\end{tabular}

Table 4. Susceptibility status to temephos of Aedes aegypti from Jalan Gedang Village and Lingkar Barat Village, Bengkulu City, Indonesia.

\begin{tabular}{|c|c|c|c|c|c|c|c|c|c|c|c|}
\hline \multirow[t]{2}{*}{ Location } & \multirow{2}{*}{$\begin{array}{l}\text { Gener } \\
\text { ation }\end{array}$} & \multicolumn{6}{|c|}{ Mortality after exposure for 24 hours (\%) } & \multirow{2}{*}{$\begin{array}{l}\text { Susceptibi } \\
\text { lity Status }\end{array}$} & \multirow{2}{*}{$\begin{array}{c}\mathrm{LC}_{50} \\
\text { (ppm } \\
\text { ) }\end{array}$} & \multirow{2}{*}{$\begin{array}{l}\mathrm{LC}_{90} \\
(\mathrm{ppm})\end{array}$} & \multirow{2}{*}{$\begin{array}{c}p \\
\text { value }\end{array}$} \\
\hline & & $\begin{array}{c}\text { Contro } \\
l\end{array}$ & $\begin{array}{c}0.003 \\
\mathrm{ppm}\end{array}$ & $\begin{array}{c}0.006 \\
\text { ppm }\end{array}$ & $\begin{array}{c}0.012 \\
\mathrm{ppm}\end{array}$ & $\begin{array}{c}0.024 \\
\mathrm{ppm}\end{array}$ & $\begin{array}{c}0.04 \\
8 \\
\text { ppm }\end{array}$ & & & & \\
\hline $\begin{array}{l}\text { Jalan } \\
\text { Gedang }\end{array}$ & F1 & 0 & 3.75 & 8.75 & 21.25 & 17.5 & $\begin{array}{c}18.7 \\
5\end{array}$ & $\begin{array}{c}\text { Highly } \\
\text { resistant }\end{array}$ & 1.005 & 1.784 & 0.00 \\
\hline $\begin{array}{l}\text { Lingkar } \\
\text { Barat }\end{array}$ & F1 & 0 & 3.75 & 6.25 & 13.75 & 15 & $\begin{array}{c}16.2 \\
5\end{array}$ & $\begin{array}{l}\text { Highly } \\
\text { resistant }\end{array}$ & 0.667 & 6.312 & 0.01 \\
\hline $\begin{array}{l}\text { Number } \\
\text { of } \\
\text { larvae }\end{array}$ & & 120 & 120 & 120 & 120 & 120 & 120 & & & & \\
\hline
\end{tabular}

\section{DISCUSSION}

In dengue endemic areas, detection of mosquito vector resistant to insecticides is very important for effective vector control. This research shows larvae dengue vector Ae. aegypti collected from
Jalan Gedang and Lingkar Barat Villages, Gading Cempaka District, Bengkulu City in Nophember until December 2019 is highly resistant to temephos. Temephos has been massively used since the 1970's in Indonesia (>40 years of duration) and in Bengkulu City since the 1980's (>30 years of duration) for larval vector control. 
Similar results were reported from Tasikmalaya ${ }^{23}$, Banjarmasin ${ }^{24}$, West Java ${ }^{25}$, Bengkulu ${ }^{26}$ and Sumbawa ${ }^{27}$ in Indonesia of Ae. aegypti larvae resistant to temephos. Georghiou and Mellon (1983) reported insect resistance to insecticide generally occurs after a period of 2-20 years of introduction. ${ }^{28}$

The mechanism of insecticide resistance in mosquitoes are being carefully examined because understanding pathways of resistance development can aid in developing preventive strategies and delaying insecticide resistance. ${ }^{29}$ High percentage of dengue-infected mosquitoes in public places is especially of concern as the likelihood of transmission is greater in this areas, resulting in the spread of infection to previously disease-free residental areas. ${ }^{30}$

The container index shows the percentage of container positively infested with larvae of Aedes aegypti. The results of this study show that the average $\mathrm{Cl}$ values in each village, namely Jalan Gedang and Lingkar Barat, were 1.97\% and 3.43\% respectively. The most common types of containers with water found in Gedang Jalan village were 82 water containers in the bath room (23.16\%), while in Lingkar Barat village the most common containers were vases 82 units (23.43\%). This is in line with research conducted by Sambuaga in 2011 in Manado, where the most commonly found containers were bathtubs/toilets, totalling 556 in number $(27.11 \%) .{ }^{31}$ The most positive type of larvae container found in Jalan Gedang was tubs (1.13\%), while in Lingkar Barat village it was vase (1.42\%).

The $\mathrm{Cl}$ parameters in Lingkar Barat village are higher than those in Jalan Gedang village, at $3.43 \%$. This parameter is used as an important comparison in evaluating vector control programs. The $\mathrm{Cl}$ value represents the number of positive containers compared to all containers examined in the area, so the $\mathrm{Cl}$ value is the percentage of positive containers that have larvae. The $\mathrm{Cl}$ value provides information on the proportion of containers containing $>1$ adult mosquito, not taking into account the variation or density of adult mosquitoes. ${ }^{24}$

The CPI is the number of pupa positive containers, divided by the examined containers. This method is used to estimate the number of mosquitoes that will appear in 2 days' time and to predict the rate of dengue transmission. The results of this study show that the average CPI values in each village, namely Jalan Gedang and Lingkar Barat, were 5\% and $2 \%$ respectively.

The $\mathrm{HI}$ and $\mathrm{Cl}$ parameters in Jalan Gedang are lower than those in Lingkar Barat village, but the CPI parameters in Jalan Gedang village are higher than Lingkar Barat village, at 5\%. The CPI parameter shows the density of adult mosquitoes in the near future, within around 2 days. The total number of pupae Aedes $s p$ is used as the closest indicator to predict the number of adult mosquitoes.

The entomological parameters of $\mathrm{HI}, \mathrm{Cl}$ and $\mathrm{CPI}$ have direct relevance to the dynamics of disease transmission. However, the threshold level of vector infestation, which is a trigger for dengue transmission, is influenced by many factors, such as the age of the mosquitoes and individual's immunological status. Research conducted by Vijayakumar (2014) in India on the high Aedes larvae breeding index in Thiruvananthapuram district showed Aedes could cause outbreaks. ${ }^{32}$

The proportion of controllable site containers in this study is higher than that in disposable sites. It can be seen that healthy living behavior in these two areas must be improved so that disposable sites can be further reduced. This shows that houses have a high risk as breeding places for mosquitoes. Awareness sanitation in the home and surrounding environment must be possessed by each individual community in order to prevent and overcome the incidence of dengue. Efforts from all sectors, including the government and community sectors, is needed. Negligence in managing the environment, leading to the creation of larvae, must be managed properly. In addition, endemic and coastal areas may also cause a higher risk of transmission. Other efforts that need to be made are vector control interventions, such as biology, chemistry and environmental management. Several studies on the effects of dengue vector control interventions on entomological parameters have been conducted. ${ }^{33}$

\section{CONCLUSION}

In summary, Aedes aegypti larvae in dengue endemic areas (Jalan Gedang Village and Lingkar Barat Village) were highly resistant to temephos. In order to reduce the development of insecticidal resistance, it recommended insecticides of different chemical structures be applied in rotation.

The entomological parameters in the form of $\mathrm{HI}$, $\mathrm{Cl}$ and $\mathrm{CPI}$ in Lingkar Barat village and Jalan Gedang village of Bengkulu City were high enough to indicate a potential risk of dengue transmission. There is a significant relationship between regional endemicity and the entomological parameters $(\mathrm{HI}, \mathrm{Cl}$ and $\mathrm{CPI}$ ), indicating high risk as breeding places for mosquitoes. Bengkulu Province is an endemic area for dengue, so it must actively develop efforts to overcome it by increasing community empowerment and building strong commitment between the local government and the community to the eradication of mosquito breeding activities.

\section{Conflict of interest}

The authors declare no potential conflict of interest. 


\section{ACKNOWLEDGMENTS}

The author would like to thank the Universitas Bengkulu, Faculty of Medicine and Health Sciences, for the research grant (contract number: 1658/UN30.14/KS/2019).

\section{REFERENCES}

1. Gubler D. Epidemic dengue/dengue hemorrhagic fever as a public health, social and economic problem in the 21st century. Trends Microbiol. 2002;10:100-3.

2. WHO. Global Strategy for Dengue Prevention and Control 2012-2020. WHO. 2012. 1-34 p.

3. Ministry of Health of Indonesia. INFODATIN (Situasi Demam Berdarah Dengue di Indonesia). Jakarta Selatan; 2016.

4. WHO. Comprehensive Guidelines for Prevention and Control of Dengue and Dengue Haemorrhagic Fever. WHO Regional Publication SEARO. 2011. 1-195 p.

5. WHO. Dengue Guidelines for Diagnosis, Treatment, Prevention and Control. WHO Library Cataloguing in Publication Data Dengue. 2009. 1-147 p.

6. Ministry of Health of Indonesia. Riset Kesehatan Dasar 2013. 2013.

7. Arslan A, Rathor HR, Mukhtar MU, Mushtaq $S$, Bhatti A, Asif $M$, et al. Spatial Distribution and Insecticide Susceptibility Status of Aedes aegypti and Aedes albopictus In Dengue Affected Urban Areas of Rawalpindi, Pakistan. J Vector Borne Dis. 2016;53(2):136-43.

8. Kamgang $B$, Marcombe $S$, Chandre $F$, Nchoutpouen E, Nwane P, Etang J, et al. Insecticide Susceptibility of Aedes aegypti and Aedes albopictus in Central Africa. Parasit Vectors 2011;4(1):79-86.

9. Sukowati S. Penggunaan Metode Survei Pupa Untuk Memprediksi Risiko Penularan Demam Berdarah Dengue Di Lima Wilayah Endemis Di Dki Jakarta. Media Heal Res Dev. 2013;23(1):31-40.

10. Mardihusodo SJ, Satoto TBT, Mulyaningsih B, Umniyati SR, Ernaningsih. Pupal Demographic and Adult Aspiration Survey of Residental and Public Sites in Yogyakarta, Indonesia to Inform Development of Targeted Sources Control Strategy for Dengue. Dengue Bull. 2011;35:141-51.

11. Arunachalam N, Tana S, Espino $\mathrm{F}$,
Kittayapong P, Abeyewickreme W, Whai $\mathrm{KT}$, et al. Eco-Bio-Social Determinans of Dengue Vector Breeding; A Multicountry Study In Urban and Periurban Asia. Bull World Heal Org. 2010;88:173-84.

12. Selvan S, Jebanesan A, Reetha D. Entomofaunal diversity of tree hole mosquitoes in Western and Eastern Ghats hill ranges of Tamilnadu, India. Acta Trop. 2016 Jul 1;159:69-82.

13. Mullen GR (Gary R, Durden LA. Medical and veterinary entomology. London: Elsevier; 2009. 627 p.

14. Selvan S, Jebanesan A. Survey and Epidemiology of Tree Hole Breeding Mosquitoes In Annamalai, University Campus, Tamilnadu, India. Int J Curr Res. 2014;6(5):6462-5.

15. Ministry of Health of Indonesia. Profil Kesehatan Indonesia Tahun 2017. Ministry of Health of Indonesia. Jakarta; 2018. 107-108 $p$

16. WHO. World Health Organization, Regional Office for South-East Asia. Comprehensive Guideline for Prevention and Control of Dengue and Dengue Haemorrhagic Fever. Revised and expanded edition. WHO Regional Office for South-East Asia. 2011.

17. WHO. Global Strategic Framework for Integrated Vector Management. World Health Organization. Geneva; 2004.

18. Bhat MA, Krishnamoorthy K. Original Research Article Entomological investigation and distribution of Aedes mosquitoes in. Int J Curr Microbiol Appl Sci. 2014;3(10):253-60.

19. Abbott WS. A Method of Computing The Effectiveness of an Insecticide. JAMCA. 1987;3(2):302-3.

20. WHO. Monitoring and Managing Insecticide Resistance in Aedes Mosquito Populations: Interim Guidance for Entomologist. Geneva; 2016.

21. BMKG. Data Online - Pusat Database BMKG [Internet]. Badan Meteorologi, Klimatologi dan Geofisika (BMKG) Stasiun Meteorologi Fatmawati Soekarno. 2020 [cited 2020 Jul 19]. p. 1-2. Available from: http://dataonline.bmkg.go.id/home

22. Minhas S, Sekhon H. Entomological Survey for Dengue Vector in an Institutional Campus to Determine Whether Potential of Dengue Outbreak Exixts. Int J Med Appl 
Sci. 2013;2(4):164-71.

23. Fuadzy H, Hendri J. Indeks Entomologi dan Kerentanan Larva Aedes aegypti Terhadap Temefos di Kelurahan Karsamenak Kecamatan Kawalu Kota Tasikmalaya. Vektora J Vektor dan Reserv Penyakit. 2015;7(2):57-64.

24. Istiana, Heriyani F, Isnaini. Resistance Status of Aedes aegypti Larvae to Temephos in West Banjarmasin. J Epidemiol dan Penyakit Bersumber Binatang. 2012;4(2):53-8.

25. Prasetyowati $\mathrm{H}$, Hendri J, Wahono $\mathrm{T}$. Status Resistensi Aedes aegypti (Linn.) terhadap Organofosfat di Tiga Kotamadya DKI Jakarta. Balaba J Litbang Pengendali Penyakit Bersumber Binatang Banjarnegara. 2016;12(1): 1-8.

26. Triana D, Umniyati SR, Mulyaningsih B. Resistance status of aedes aegypti to malathion and cypermethrin in Bengkulu city, Indonesia. Southeast Asian J Trop Med Public Health. 2019;50(3):461-8.

27. Simbawara L. Status Resistensi Aedes aegypti Terhadap Malation Dan Temefos Serta Distribusi Spasialnya Di Daerah Endemis DBD Kabupaten Sumbawa Lalu Simbawara. [Thesis]. Sekolah Pascasarjana Institut Pertanian Bogor. 2017.
28. Georghiou GP, Mellon RB. Pesticide Resistance in Time and Space. In: Pest Resistance to Pesticides. New York: Plenum Press; 1983.

29. Hemingway J, Hawkes NJ, Mccarroll L, Ranson H. The Molecular Basis of Insecticide Resistance in Mosquitoes. Insect Biochem Mol Biol. 2004;34:653-65.

30. Ming LS, Adnan TH, Huck OC, Ibrahim M, Husin D, Abdullah NA, et al. Adult Aedes Mosquito And Dengue Virus Surveillance In Residential And Public Areas Of Selangor, Malaysia. Southeast Asean J Trop Med Public Heal. 2018;49(4):553-65.

31. Sambuaga JVI. Status Entomologi Vektor Demam Berdarah Dengue di Kelurahan Perkamil Kecamatan Tikala Kota Manado Tahun 2011. J Kesehat Lingkung. 2011;1(1):54-61.

32. Vijayakumar K, Sudheesh Kumar TK, Nujum ZT, Umarul F, Kuriakose A. A study on container breeding mosquitoes with special reference to Aedes (Stegomyia) aegypti and Aedes albopictus in Thiruvananthapuram district, India. J Vector Borne Dis., 2014;51(1):27-32.

33. Sivagnaname N, Gunasekaran K. Need for an efficient adult trap for the surveillance of dengue vectors. Indian J Med Res. 2012;136(5):739-49. 